\title{
NITROGENOUS COMPOUNDS AND OXYGEN CONCENTRATION AS THE KEY DENSITY DEPENDENT FACTORS TO OPTIMIZE GROWTH OF BELUGA, HUSO HUSO (ACTINOPTERYGII: ACIPENSERIFORMES: ACIPENSERIDAE), IN CIRCULAR FIBERGLASS TANKS
}

\author{
Saeedeh RAFATNEZHAD ${ }^{1,2}$ and Bahram FALAHATKAR ${ }^{1 *}$ \\ ${ }^{1}$ Fisheries Department, Faculty of Natural Resources, University of Guilan, Sowmeh Sara, Guilan, 1144, Iran \\ ${ }^{2}$ Department of Environmental Science, Islamic Azad University of Damavand, \\ Young Researchers Club of Damavand, Tehran, Iran
}

Rafatnezhad S., Falahatkar B. 2011. Nitrogenous compounds and oxygen concentration as the key density dependent factors to optimize growth of beluga, Huso huso (Actinopterygii: Acipenseriformes: Acipenseridae), in circular fiberglass tanks. Acta Ichthyol. Piscat. 41 (4): 285-291.

\begin{abstract}
Background. Beluga, Huso huso, known also as the great sturgeon, is a valuable fish in terms of meat and caviar production. It has been implicated that intensive fish culture is a major culprit for deterioration of water quality through metabolic excretion of fish in the aquatic environment. The aims of this study were: to determine the effect of the stocking density on the water quality, to assess the effect of water quality changes on growth of beluga juveniles, and also to determine the optimum density for culture in fiberglass tanks.

Materials and methods. Fish were randomly distributed into 15 tanks at 5 different densities including $1 \mathrm{~kg} \cdot \mathrm{m}^{-2}$ $\left(3.90 \mathrm{~kg} \mathrm{~m}{ }^{-3}\right), 2 \mathrm{~kg} \cdot \mathrm{m}^{-2}\left(7.09 \mathrm{~kg} \cdot \mathrm{m}^{-3}\right), 4 \mathrm{~kg} \cdot \mathrm{m}^{-2}\left(14.54 \mathrm{~kg} \cdot \mathrm{m}^{-3}\right), 6 \mathrm{~kg} \cdot \mathrm{m}^{-2}\left(21.19 \mathrm{~kg} \cdot \mathrm{m}^{-3}\right)$, and $8 \mathrm{~kg} \cdot \mathrm{m}^{-2}$ $\left(28.64 \mathrm{~kg} \cdot \mathrm{m}^{-3}\right)$ with 3 replicates. Specific growth rate (SGR), yield $(Y)$, average daily growth (ADG), absolute weight gain (AWG), and relative weight gain (RWG) were calculated. Throughout the experiment, water quality parameters including ammonia $\left(\mathrm{NH}_{3}\right)$, nitrite $\left(\mathrm{NO}_{2}\right)$, nitrate $\left(\mathrm{NO}_{3}\right)$ dissolved oxygen (DO), and oxygen saturation (OS) were also measured. Results. Stocking density considerably influences the growth of beluga juveniles and water quality during 56 days of rearing. $\mathrm{DO}, \mathrm{OS}, \mathrm{NO}_{2}, \mathrm{NO}_{3}$, and $\mathrm{NH}_{3}$ were significantly different among treatments. $\mathrm{pH}$ and temperature showed no significant effect under different stocking densities. $\mathrm{NO}_{2}$ and $\mathrm{NO}_{3}$ increased, while DO decrease as the stocking density of fish increased. At the end of the 56 days of rearing, all the growth parameters (final weight, total length, SGR, $Y, \mathrm{ADG}, \mathrm{AWG}$, and RWG) were significantly different among treatments. Survival was $100 \%$ in all of the rearing densities.

Conclusion. Results of this study showed that the density of fish had a significant effect on water quality and a high density culture accompanied by intensive feeding may result in high concentrations of nitrogen compounds, and low concentrations of dissolved oxygen in the water of culture tanks. Each of the factors (increase nitrogenous compounds and decrease in oxygen) could suppress the growth of Huso huso juveniles.
\end{abstract}

Keywords: stocking density, water quality, growth, ammonia, beluga, great sturgeon, Huso huso

\section{INTRODUCTION}

Beluga, Huso huso, known also as the great- or giant sturgeon, is one of the most common species of sturgeon cultured in Russia, Eastern Europe, Japan, and Iran. It has also been of commercial interest in other countries for over a decade. This is primarily because of the highest market value of caviar and the depletion, or in some cases decimation, of wild sturgeon stocks throughout the world (Birstein et al. 1997). This species is suitable for aquaculture because of fast growth, reproduction in captivity, and tolerance of unfavourable rearing conditions (Vlasenko 1994, Falahatkar et al. 2009b).
Intensive fish farming has been based upon the premise that it utilizes a minimum of land and water resources while providing maximum profit to the farmers (Biswas et al. 2006).

Ammonia is the main end product of nitrogen metabolism in teleosts and it exists in both ionized $\left(\mathrm{NH}_{4}{ }^{+}\right)$and unionized $\left(\mathrm{NH}_{3}\right)$ forms. The toxicity of ammonia to fish and other aquatic organisms is primarily attributed to the unionized form. Tolerance of exposure to chronic unionized ammonia varies widely among species, with threshold values for long-term negative effect on growth in fish ranging from $0.01 \mathrm{mg} \cdot \mathrm{L}^{-1}$ in salmonids (Arillo et al. 1981) to $0.30 \mathrm{mg} \cdot \mathrm{L}^{-1}$ in gilthead seabream, Sparus aurata (see

\footnotetext{
${ }^{*}$ Correspondence: Dr. Bahram Falahatkar, Fisheries Department, Faculty of Natural Resources, University of Guilan, Sowmeh Sara, 1144 , Guilan, Iran, phone: +98 182 322 3599, fax: +98 182322 2102, e-mail: falahatkar@guilan.ac.ir.
} 
Wajsbrot et al. 1993). A preliminary study on the effects of ammonia on growth in spotted wolffish, Anarhichas minor, at normoxic levels indicated a threshold level between 0.07 and $0.2 \mathrm{mg} \cdot \mathrm{L}^{-1}$ at which growth was reduced (see Foss et al. 2003).

In the rearing of sturgeons, the tank area is more critical factor (unit square meter) than tank volume (unit cubic meter), because this group of fishes exhibits benthic-orientation. A study on lake sturgeon, Acipenser fulvescens, indicates that due to the benthic orientation, the tank area is more critical than the tank volume (Fajfer et al. 1999).

Despite the importance of sturgeon culture, little is known about the optimal rearing density for most of species. This study has been done for the first time to find the effect of different stocking density of beluga juveniles on water quality parameters with main focus on nitrogenous compounds and oxygen concentration that are so important to optimization of stocking density in rearing of most cultured fish. Therefore, it is proposed that the results would be useful in raising the beluga in small tanks during the first year of rearing.

\section{MATERIALS AND METHODS}

Experimental design and maintenance of fish. The study was conducted at the Shahid Dr. Beheshti Sturgeon Fish Propagation and Rearing Complex, in Rasht, Guilan, Iran, using beluga juveniles with initial weight of $93.13 \pm 1.04 \mathrm{~g}$ (mean weight $\pm \mathrm{SE}$ ) which were artificially propagated at the same hatchery, and adapted to artificial diet. Fish were randomly distributed into 15 tanks at 5 different densities including $1 \mathrm{~kg} \cdot \mathrm{m}^{-2}\left(3.90 \mathrm{~kg} \cdot \mathrm{m}^{-3}\right), 2 \mathrm{~kg} \cdot \mathrm{m}^{-2}\left(7.09 \mathrm{~kg} \cdot \mathrm{m}^{-3}\right)$, $4 \mathrm{~kg} \cdot \mathrm{m}^{-2}\left(14.54 \mathrm{~kg} \cdot \mathrm{m}^{-3}\right), 6 \mathrm{~kg} \cdot \mathrm{m}^{-2}\left(21.19 \mathrm{~kg} \cdot \mathrm{m}^{-3}\right)$, and $8 \mathrm{~kg} \cdot \mathrm{m}^{-2}\left(28.64 \mathrm{~kg} \cdot \mathrm{m}^{-3}\right)$ with 3 replicates. The number of fish per tank for each treatment was 44, 80, 164, 239, and 323 in densities $1-8 \mathrm{~kg} \cdot \mathrm{m}^{-2}$, respectively. The dimensions of rearing fiberglass tanks were $2 \times 2 \times 0.5 \mathrm{~m}$ (with water level $30 \mathrm{~cm}, 3.5 \mathrm{~m}^{2}$ surface area and $1050 \mathrm{~L}$ volume) and with a flow-through rate of $33.6 \pm 1.0 \mathrm{~L} \cdot \mathrm{min}^{-1}$. The source of water inflow for all tanks supplied from filtered water of the Sefidroud River. Beside the experimental tanks, a similar tank was considered without fish for monitoring the water quality parameters as well. All tanks were uniformly aerated and equipped with an air pipe. Water temperature was $22.8 \pm 0.7^{\circ} \mathrm{C}$ during the experimental period.

Prior to the initiation of the experiment, fish were acclimatized to experimental condition for two weeks. Feed was offered three times $(0900,1430$, and $2300 \mathrm{~h}$ ) daily with a dry commercial diet designed for sturgeon according to the palatability, nutritional requirements and stability in water (Biomar, No. 1.9, 50\% crude protein, $18 \%$ crude fat, $10 \%$ ash, $1.3 \%$ fibre). The duration of experiment was 56 days. Food was supplied as $1.5 \%-3 \%$ body weight (BW) daily, according to water temperature during the experimental period and our previous finding on this species (Mohseni et al. 2006, Falahatkar et al. 2009a). Uneaten feed were collected at the outflow of each tank by the inserted screen and counted the pellets to calculate the total feed consumption.
Growth performance. Body weight and total length were recorded on a 2-week interval biometry. Feeding rates were adjusted bi-weekly to increase average weight of fish in each tank. Specific growth rate $[\mathrm{SGR}=(\mathrm{Ln}$ final weight - Ln initial weight) / days $\times 100]$, yield $[Y=$ final biomass $\left(\mathrm{kg} \cdot \mathrm{m}^{-2}\right)$ - initial biomass $\left.\left(\mathrm{kg} \cdot \mathrm{m}^{-2}\right)\right]$, average daily growth $\left[\mathrm{ADG}=W_{2}-W_{1} \times 100 / W_{1} \times\left(t_{2}-t_{1}\right)\right]$, absolute weight gain $\left[\mathrm{AWG}=B_{t}-B_{0} / n \times T\right]$, and relative weight gain $\left[\mathrm{RWG}=\left(\mathrm{AWG} / W_{t}\right) \times 100\right]$ were calculated $\left(B_{t}=\right.$ sole biomass $(\mathrm{g})$ at day $56 ; B_{0}=$ sole biomass $(\mathrm{g})$ at initial sampling at day $0 ; n=$ number of individuals; $T=$ duration of the experiment (days), $W_{t}=$ fish average weight $(\mathrm{g})$ at day 0$)$.

Water quality analysis. Throughout the experiment, the following water quality parameters were measured using the inflow and outflow of each experimental tank: $\mathrm{pH}$ using commercial test kit (Aquamerck; Merck, Darmstadt, Germany), total dissolved solids (TDS) and total suspended solids (TSS) by dry weight, Heater Plate (Iran-Lab, Tehran, Iran), orthophosphates $\left(\mathrm{PO}_{4}-\mathrm{P}\right)$, ammonia $\left(\mathrm{NH}_{3}\right)$, nitrite $\left(\mathrm{NO}_{2}\right)$, and nitrate $\left(\mathrm{NO}_{3}\right)$ using photometer (Model Pc22; Tintometer, GmBH, Dortmund, Germany). Dissolved oxygen (DO), temperature (T) and oxygen saturation (OS), were also measured daily by oxymeter (WTW oxi 330i, Weilheim, Germany).

Samples of water were collected from each tank at a fixed hour of the each day $(1000 \mathrm{~h})$ for determination of different kinds of nitrogen compounds (ammonia-N, nitrite-N, and nitrate-N), and other water quality parameters (temperature, $\mathrm{pH}, \mathrm{DO}$ ) according to the standard methods (Anonymous 1994, 1998).

Statistical analyses. Results were analyzed by oneway analysis of variance and further comparisons among treatment means were made by Tukey's test as post-hoc test using SPSS software (SPSS version 13. Chicago, IL). Linear regression models (Excel, Microsoft Office 2003) were also applied to each stocking density to determine the relation between different parameters. Statistical significance was conducted at $P \leq 0.05$ level. All data are presented as mean $\pm \mathrm{SE}$.

\section{RESULTS}

Water quality. Water quality parameters from the inflow and outflow of each experimental tank are given in Tables 1 and 2. Water temperature $\left(22.3^{\circ} \mathrm{C}\right.$ to $\left.23.0^{\circ} \mathrm{C}\right)$ and $\mathrm{pH}(8.0)$ remained within the range of tolerance for fish growth during the entire period of study. DO $\left(\mathrm{mg} \cdot \mathrm{L}^{-1}\right)$, OS $(\%), \mathrm{NO}_{2}\left(\mathrm{mg} \cdot \mathrm{L}^{-1}\right)$, and $\mathrm{NO}_{3}\left(\mathrm{mg} \cdot \mathrm{L}^{-1}\right)$ were significantly different among treatments $(P<0.05$; Table 2$)$.

Fish growth. The final biomass measures from the lowest to the highest densities were 4.0, 6.5, 11.0, 14.5, and $17.1 \mathrm{~kg} \cdot \mathrm{m}^{-2}$, respectively. At the end of the 56 days of rearing, all the growth parameters (final weight, total length, SGR, $Y$, ADG, AWG, and RWG) were significantly different among treatments $(P<0.05$; Table 3$)$. Survival was $100 \%$ in all of the rearing densities.

Relation between dissolved oxygen, ammonia and nitrite concentrations with fish growth. Dissolved oxy- 
gen concentration was recorded to be decreasing with increasing density.

An inverse relation between the dissolved oxygen (4.7-7.8 $\mathrm{mg} \cdot \mathrm{L}^{-1}$ ) and density of beluga juvenile was clearly demonstrated in the present study (Fig. 1). When DO levels were $4.7 \mathrm{mg} \cdot \mathrm{L}^{-1}$, specific growth rate was $1.6 \pm 0.03 \%$ day $^{-1}$, while values of $7.8 \mathrm{mg} \cdot \mathrm{L}^{-1}$ were associated with $2.6 \pm 0.03 \%$ day $^{-1}$ at the highest $\left(8 \mathrm{~kg} \cdot \mathrm{m}^{-2}\right)$ and lowest $\left(1 \mathrm{~kg} \cdot \mathrm{m}^{-2}\right)$ densities, respectively.

High relation was observed between dissolved oxygen-ammonia ratio and average growth rate $\left(R^{2}=0.9616\right.$; Fig. 2). Also the relation between dissolved oxygen-nitrate ratio and average growth rate was high $\left(R^{2}=0.9397\right.$; Fig. 3$)$. The concentrations of $\mathrm{NO}_{2}\left(0.00-0.08 \mathrm{mg} \cdot \mathrm{L}^{-1} ; P=0.000\right)$ and $\mathrm{NH}_{3}\left(0.42-0.73 \mathrm{mg} \cdot \mathrm{L}^{-1} ; P=0.034\right)$ as well as $\mathrm{NO}_{3}$ $\left(2.62-3.53 \mathrm{mg} \cdot \mathrm{L}^{-1} ; P=0.037\right)$ of water were found to be directly related to the stocking density of fish.

Relations between the amounts of feed consumed, ammonia and nitrite concentrations with fish growth. Fig. 4 shows the relation between the amounts of feed consumed, ammonia and nitrite concentrations with growth in beluga juvenile under different stocking densities. The amount of feed consumed during 56 days showed a significant difference among different densities $\left(1,2,4,6\right.$, and $\left.8 \mathrm{~kg} \cdot \mathrm{m}^{-2} ; P=0.000\right)$.

\section{DISCUSSION}

Water quality. The physicochemical parameters including $\mathrm{DO}, \mathrm{OS}, \mathrm{NO}_{2}, \mathrm{NO}_{3}$, and $\mathrm{NH}_{3}$ were found significantly different among treatments. Each of the factors (increase nitrogenous compounds and decrease in oxygen) could regulate the growth of Huso huso juveniles. $\mathrm{pH}$ was not significantly different among treatments. The water inflows into the tanks were maintained at a uniform delivery rate of $33.6 \pm 1.0 \mathrm{~L} \cdot \mathrm{min}^{-1}$ for all treatments with good aeration. Results show that water quality was significantly influenced by fish stocking density.

The concentration of $\mathrm{NO}_{2}\left(0.00-0.08 \mathrm{mg} \cdot \mathrm{L}^{-1}\right)$ and $\mathrm{NO}_{3}\left(2.62-3.53 \mathrm{mg} \cdot \mathrm{L}^{-1}\right)$ were found to be directly related to the stocking density of fish, suggesting that the den-

Physico-chemical parameters of tanks water inflow (water from the Sangar Dam, Sefidroud River)

Table 1 during the culture of beluga Huso huso juveniles

\begin{tabular}{ccccccccc}
\hline $\begin{array}{c}\mathrm{DO} \\
{\left[\mathrm{mg} \cdot \mathrm{L}^{-1}\right]}\end{array}$ & $\begin{array}{c}\mathrm{OS} \\
{[\%]}\end{array}$ & $\mathrm{pH}$ & $\begin{array}{c}\mathrm{NO}_{2} \\
{\left[\mathrm{mg} \cdot \mathrm{L}^{-1}\right]}\end{array}$ & $\begin{array}{c}\mathrm{NO}_{3} \\
{\left[\mathrm{mg} \cdot \mathrm{L}^{-1}\right]}\end{array}$ & $\begin{array}{c}\mathrm{NH}_{3} \\
{\left[\mathrm{mg} \cdot \mathrm{L}^{-1}\right]}\end{array}$ & $\begin{array}{c}\mathrm{PO}_{4}^{-\mathrm{P}} \\
{\left[\mathrm{mg} \cdot \mathrm{L}^{-1}\right]}\end{array}$ & $\begin{array}{c}\mathrm{TDS} \\
{\left[\mathrm{mg} \cdot \mathrm{L}^{-1}\right]}\end{array}$ & $\begin{array}{c}\text { TSS } \\
{\left[\mathrm{mg} \cdot \mathrm{L}^{-1}\right]}\end{array}$ \\
\hline $7.47 \pm 0.11$ & $80.67 \pm 1.47$ & $8.02 \pm 0.04$ & $0.00 \pm 0.00$ & $0.67 \pm 0.03$ & $0.01 \pm 0.00$ & $0.02 \pm 0.01$ & $21.51 \pm 3.27$ & $0.05 \pm 0.02$ \\
\hline
\end{tabular}

$\mathrm{DO}=$ dissolved oxygen, $\mathrm{OS}=$ oxygen saturation, $\mathrm{NO}_{2}=$ nitrite, $\mathrm{NO}_{3}=$ nitrate, $\mathrm{NH}_{3}=$ ammonia, $\mathrm{PO}_{4}-\mathrm{P}=$ orthophosphates, $\mathrm{TDS}=$ total dissolved solids, $\mathrm{TSS}=$ total suspended solid; Values are mean $\pm \mathrm{SE}$.

Table 2

Physico-chemical parameters of tanks water outflow during the culture of beluga, Huso huso, juveniles under different stocking densities

\begin{tabular}{|c|c|c|c|c|c|c|c|}
\hline $\begin{array}{c}\text { Stocking } \\
\text { density } \\
{\left[\mathrm{kg} \cdot \mathrm{m}^{-2}\right]}\end{array}$ & $\begin{array}{c}\mathrm{DO} \\
{\left[\mathrm{mg} \cdot \mathrm{L}^{-1}\right]}\end{array}$ & $\begin{array}{l}\mathrm{OS} \\
{[\%]}\end{array}$ & $\mathrm{pH}$ & $\begin{array}{c}\mathrm{T} \\
{\left[{ }^{\circ} \mathrm{C}\right]}\end{array}$ & $\begin{array}{c}\mathrm{NO}_{2} \\
{\left[\mathrm{mg} \cdot \mathrm{L}^{-1}\right]}\end{array}$ & $\begin{array}{c}\mathrm{NO}_{3} \\
{\left[\mathrm{mg} \cdot \mathrm{L}^{-1}\right]}\end{array}$ & $\begin{array}{c}\mathrm{NH}_{3} \\
{\left[\mathrm{mg} \cdot \mathrm{L}^{-1}\right]}\end{array}$ \\
\hline 1 & $7.8 \pm 0.36^{\mathrm{a}}$ & $87.4 \pm 1.84^{\mathrm{a}}$ & $8.05 \pm 0.01$ & $23.09 \pm 0.50$ & $0.00 \pm 0.00^{c}$ & $2.62 \pm 0.12^{b}$ & $0.42 \pm 0.08^{b}$ \\
\hline 2 & $7.2 \pm 0.20^{\mathrm{a}}$ & $82.5 \pm 2.05^{\mathrm{a}}$ & $8.04 \pm 0.00$ & $22.95 \pm 0.47$ & $0.00 \pm 0.00^{\mathrm{c}}$ & $3.12 \pm 0.17^{\mathrm{ab}}$ & $0.55 \pm 0.05^{\mathrm{ab}}$ \\
\hline 4 & $5.7 \pm 0.04^{\mathrm{b}}$ & $65.6 \pm 0.36^{\mathrm{b}}$ & $8.00 \pm 0.01$ & $22.52 \pm 0.24$ & $0.01 \pm 0.01^{\mathrm{bc}}$ & $2.90 \pm 0.13^{\mathrm{ab}}$ & $0.52 \pm 0.09^{\mathrm{ab}}$ \\
\hline 6 & $5.1 \pm 0.10^{\mathrm{bc}}$ & $59.3 \pm 0.35^{\mathrm{bc}}$ & $8.07 \pm 0.00$ & $22.66 \pm 0.47$ & $0.05 \pm 0.01^{\mathrm{ab}}$ & $3.53 \pm 0.19^{\mathrm{a}}$ & $0.72 \pm 0.01^{\mathrm{a}}$ \\
\hline 8 & $4.7 \pm 0.19^{c}$ & $54.1 \pm 1.87^{\mathrm{c}}$ & $8.10 \pm 0.05$ & $22.88 \pm 0.49$ & $0.08 \pm 0.01^{\mathrm{a}}$ & $3.36 \pm 0.24^{\mathrm{ab}}$ & $0.73 \pm 0.03^{\mathrm{a}}$ \\
\hline
\end{tabular}

$\mathrm{DO}=$ dissolved oxygen, $\mathrm{OS}=$ oxygen saturation, $\mathrm{T}=$ temperature, $\mathrm{NO}_{2}=$ nitrite, $\mathrm{NO}_{3}=$ nitrate, $\mathrm{NH}_{3}=$ ammonia, Means identified by a different superscript in the columns $(\mathrm{a}, \mathrm{b}, \mathrm{c})$ were significantly different $(P \leq 0.05)$ as determined by ANOVA and Tukey's test for each parameter; Values are mean \pm SE.

Table 3

Different growth parameters in beluga Huso huso juveniles after 56 days rearing under different stocking densities

\begin{tabular}{ccccccccccc}
\hline $\begin{array}{c}\text { Stocking } \\
\text { density } \\
{\left[\mathrm{kg} \cdot \mathrm{m}^{-2}\right]}\end{array}$ & $\begin{array}{c}\text { Initial } \\
\text { weight } \\
{[\mathrm{g}]}\end{array}$ & $\begin{array}{c}\text { Final } \\
\text { weight } \\
{[\mathrm{g}]}\end{array}$ & $\begin{array}{c}\text { Initial } \\
\text { length } \\
{[\mathrm{cm}]}\end{array}$ & $\begin{array}{c}\text { Final } \\
\text { length } \\
{[\mathrm{cm}]}\end{array}$ & $\begin{array}{c}\text { SGR } \\
{\left[\% \mathrm{day}^{-1}\right]}\end{array}$ & $\begin{array}{c}\text { Yield } \\
{\left[\mathrm{kg} \cdot \mathrm{m}^{-2}\right]}\end{array}$ & $\begin{array}{c}\text { ADG } \\
{[\%]}\end{array}$ & $\begin{array}{c}\text { AWG } \\
{\left[\mathrm{g} \cdot \mathrm{fish}^{-1} \cdot \mathrm{day}^{-1}\right]}\end{array}$ & $\begin{array}{c}\text { RWG } \\
{\left[\% \mathrm{day}^{-1}\right]}\end{array}$ & $\begin{array}{c}\text { Survival } \\
{[\%]}\end{array}$ \\
\hline 1 & $93.13 \pm 1.04$ & $362.4 \pm 6.9^{\mathrm{a}}$ & $29.71 \pm 0.12$ & $44.0 \pm 0.28^{\mathrm{a}}$ & $2.6 \pm 0.03^{\mathrm{a}}$ & $3 \pm 0.07^{\mathrm{e}}$ & $5.16 \pm 0.13^{\mathrm{a}}$ & $3.63 \pm 0.15^{\mathrm{a}}$ & $3.90 \pm 0.16^{\mathrm{a}}$ & 100 \\
2 & $93.13 \pm 1.04$ & $319.7 \pm 2.1^{\mathrm{b}}$ & $29.71 \pm 0.12$ & $41.0 \pm 0.19^{\mathrm{b}}$ & $2.4 \pm 0.01^{\mathrm{b}}$ & $4.5 \pm 0.01^{\mathrm{d}}$ & $4.34 \pm 0.04^{\mathrm{b}}$ & $3.02 \pm 0.13^{\mathrm{b}}$ & $3.24 \pm 0.14^{\mathrm{b}}$ & 100 \\
4 & $93.13 \pm 1.04$ & $267.0 \pm 9.2^{\mathrm{c}}$ & $29.71 \pm 0.12$ & $40.1 \pm 0.19^{\mathrm{b}}$ & $2.0 \pm 0.06^{\mathrm{c}}$ & $7 \pm 0.32^{\mathrm{c}}$ & $3.33 \pm 0.17^{\mathrm{c}}$ & $2.41 \pm 0.03^{\mathrm{c}}$ & $2.58 \pm 0.03^{\mathrm{c}}$ & 100 \\
6 & $93.13 \pm 1.04$ & $242.1 \pm 6.2^{\mathrm{c}}$ & $29.71 \pm 0.12$ & $39.4 \pm 0.19^{\mathrm{c}}$ & $1.8 \pm 0.04^{\mathrm{c}}$ & $8.5 \pm 0.32^{\mathrm{b}}$ & $2.85 \pm 0.11^{\mathrm{c}}$ & $2.22 \pm 0.13^{\mathrm{cd}}$ & $2.38 \pm 0.14^{\mathrm{cd}}$ & 100 \\
8 & $93.13 \pm 1.04$ & $211.1 \pm 4.1^{\mathrm{d}}$ & $29.71 \pm 0.12$ & $37.7 \pm 0.46^{\mathrm{d}}$ & $1.6 \pm 0.03^{\mathrm{d}}$ & $9.1 \pm 0.28^{\mathrm{a}}$ & $2.26 \pm 0.07^{\mathrm{d}}$ & $1.79 \pm 0.02^{\mathrm{d}}$ & $1.92 \pm 0.02^{\mathrm{d}}$ & 100 \\
\hline
\end{tabular}

Growth parameters including fish final weight and length, specific growth rate (SGR), yield (Y), average daily growth (ADG), absolute weight gain (AWG), and relative weight gain (RWG) indicate significant differences among different densities $(P \leq 0.05)$; Means identified by a different superscript in the columns $(\mathrm{a}, \mathrm{b}, \mathrm{c}, \mathrm{d})$ were significantly different $(P \leq 0.05)$ as determined by ANOVA and Tukey's test for each parameter; Values are mean $\pm \mathrm{SE}$. 
sity dependent metabolic excrement was the major source of $\mathrm{N}$ input in the culturing system. In the present study, the concentrations of $\mathrm{NH}_{3}, \mathrm{NO}_{2}$, and $\mathrm{NO}_{3}$ were higher in tanks with high stocking densities, which seem to be related to uneaten feeds, faeces, movements of under stressed fish and excretion of ammonia from gills into the water.

Also, the $\mathrm{NO}_{2}$ and $\mathrm{NO}_{3}$ concentrations in the experimental treatments are far below the levels that impact fish health; therefore, it is difficult to say that these minor concentrations of nitrate and nitrite can affect fish growth, but $\mathrm{NH}_{3}$ concentration of 0.42 and $0.73 \mathrm{mg} \cdot \mathrm{L}^{-1}$ for density of 1 and $8 \mathrm{~kg} \cdot \mathrm{m}^{-2}$ (or 44 fish and $323 \mathrm{fish} / \operatorname{tank}$ ) was the threshold and critical values that caused growth inhibition. Therefore, mainly ammonia concentration measured in the experimental tanks was in affecting level on the growth of beluga.

Timmons et al. (2002) recommend ammonia concentration for cold water species to be lower than $0.02 \mathrm{mg} \cdot \mathrm{L}^{-1}$ and for warm water species lower than $0.6 \mathrm{mg} \cdot \mathrm{L}^{-1}$. Continuous exposure to the $\mathrm{NH}_{3}$ concentration of $0.02 \mathrm{mg} \cdot \mathrm{L}^{-1}$ results in negative impacts on the growth of rainbow trout (Arillo et al. 1981). Wedemeyer et al. (1990) reported that excessively high loading rates can lead to an accumulation of unionized ammonia, which can negatively impact the health and ultimately the growth and survival of fish in culture.

In heavily stocked production units, the rate at which fish are fed, composition of feed, metabolic rate of fish and amount of waste feed present in the system are all factors that may have major detrimental impacts on the water quality. As feed is introduced into the culture system, it is either consumed by the fish or may be left to decompose in the system. If uneaten feed and metabolic by-products are left within the culture system, they will generate carbon dioxide and ammonia-nitrogen, reduce the oxygen content of the water and have a direct detrimental impact on the health of the cultured fish (Foss et al. 2006).

Biswas et al. (2006) reported that stocking density of advanced fry of common carp depends on increase in the concentration of ammonium was attributed to fish excrement, which increased almost linearly with stocking density by $12 \%$ and $64 \%$ in the lowest and highest stocking densities, respectively. Another study showed that the density of fish and rate of feed input had significant influence on water quality and a high density culture accompanied by intensive feeding may result in high concentrations of ammonia, nitrite and phosphorus, and low concentrations of dissolved oxygen in the tank water (Al-Harbi and Siddiqui 2000). The amounts of suspended solids in the water-column will increase due to both greater faecal production and more fish movement, which prevents particles from settling (Ellis et al. 2002). Several studies on freshwater fish (Thurston et al. 1981) and gilthead seabream, Sparus aurata (see Wajsbrot et al. 1991) have demonstrated an increase in ammonia toxicity at reduced levels of DO. It is an established fact that toxicity of ammonia increases with decreasing oxygen level (Wajsbrot et al. 1991), but ammonia tolerance can be increased by rearing fish at DO levels above normal satu- ration (Foss et al. 2003, Koedijk 2005, Foss et al. 2009).

The DO levels of $4.7 \pm 0.19 \mathrm{mg} \cdot \mathrm{L}^{-1}$ and $7.8 \pm 0.36 \mathrm{mg} \cdot \mathrm{L}^{-1}$ observed in the high and low densities of fish were respectively found to be detrimental and conducive to fish growth in the present experimental conditions. An inverse relation between the dissolved oxygen $\left(4.7-7.8 \mathrm{mg} \cdot \mathrm{L}^{-1}\right)$ and density of beluga juvenile was clearly demonstrated in the present study.

The higher oxygen consumption at elevated fish den-

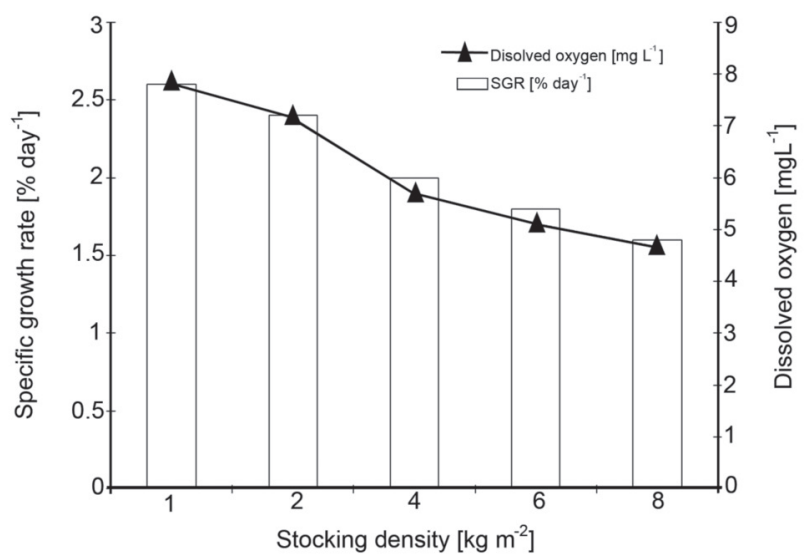

Fig. 1. Relation between dissolved oxygen and specific growth rate (SGR) in juveniles of beluga, Huso huso, under different stocking densities

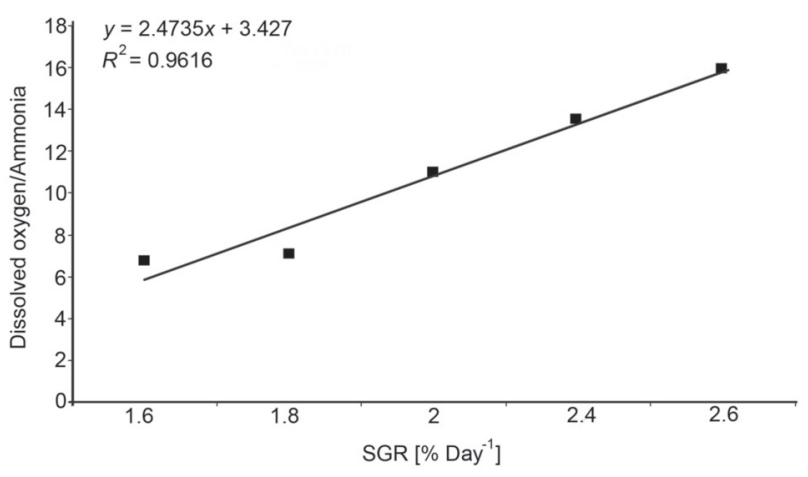

Fig. 2. Regression of dissolved oxygen-ammonia ratio and specific growth rate (SGR) in juveniles of beluga, Huso huso, under different stocking densities

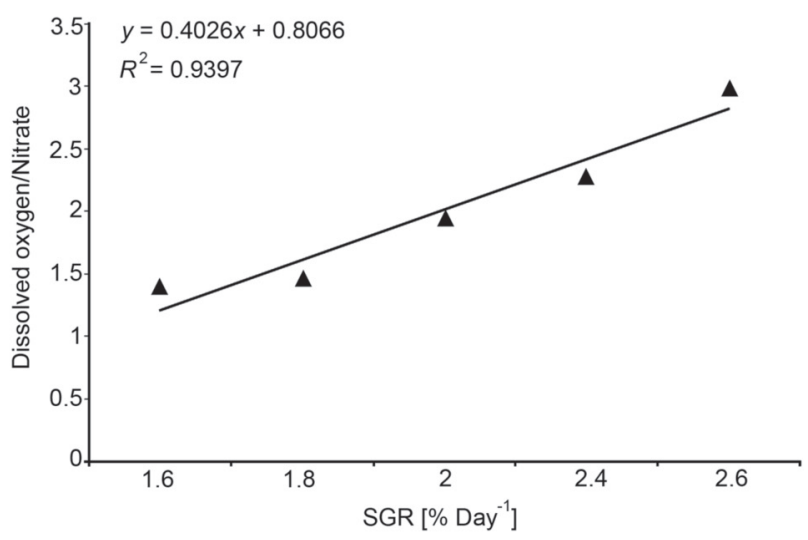

Fig. 3. Regression of dissolved oxygen-nitrate ratio and specific growth rate (SGR) in juveniles of beluga, Huso huso, under different stocking densities 
sity could also be explained by increased swimming activity observed in those fish stocked at high density (6 and $8 \mathrm{~kg} \cdot \mathrm{m}^{-2}$ ). At low densities of Senegalese sole (Solea senegalensis) juveniles, less energy expenditure is required for the feed ingested (Salas-Leiton et al. 2008). Although feed was proportionally supplied to tank biomass, both the higher swimming activity and the shorter feeding response would indicate the existence of a certain competition for food under high densities. This could means that fish stocked at low densities might feed exclusively as demanded by appetite without any extra stimuli induced by competition due to high density.

Fluctuations in oxygen concentration below optimum levels may lead to appetite reduction and growth depression (Whitworth 1968, Carlson et al. 1980). Thus, oxygen saturation levels observed during our study are unlikely to account for the decreased growth rate observed at high stocking density.

Crocker and Cech (1996) found that growth in juvenile white sturgeon, Acipenser transmontanus, was significantly reduced in fish exposed to severe hypercapnia $(\mathrm{pH} 7.0)$ as compared to normocapnia conditions ( $\mathrm{pH} 8.0)$, but it was also found that a reduced $\mathrm{pH}$ alone did not affect growth. In our study, there was no effect of stocking density on $\mathrm{pH}$ which was around 8 as normocapnia conditions.

Fish growth. Beluga juvenile attained the highest length and achieved maximum weight in stocking density of $1 \mathrm{~kg} \cdot \mathrm{m}^{-2}$, which might be due to fewer fish per unit space. High stocking density reduces the space available to each fish and therefore, growth will be affected. The decreased specific growth rate $\left(\%\right.$ day $\left.^{-1}\right)$ and yield $\left(\mathrm{kg} \cdot \mathrm{m}^{-2}\right)$ at higher stocking densities could result to poor growth of fish. This result is supported by Trenzado et al. (2006) in rainbow trout. Moreover, high density caused to reduction of average daily growth, relative weight gain and absolute weight gain.

Dissolved oxygen, besides feed and temperature, is the most important factor controlling growth, and a constant DO content below a critical level is considered to reduce feed consumption, growth and feed conversion efficiency (Jobling 1994). An interactive effect of ammonia level and oxygen saturation was found for both mean weight and condition factor (Foss et al. 2003).

Persistently low concentration of dissolved oxygen under higher stocking densities imparted negative impact on growth of beluga juvenile. Brett (1979) suggested that an oxygen concentration of about $5 \mathrm{mg} \cdot \mathrm{L}^{-1}$ is critical for an acceptable growth and feed conversion, and Jobling (1995) suggested that levels of DO which limits feed intake in fish is usually between $50 \%$ and $70 \%$ saturation. According to Boyd (1982), dissolved oxygen concentrations of $<3 \mathrm{mg} \cdot \mathrm{L}^{-1}$ and $>5.0 \mathrm{mg} \cdot \mathrm{L}^{-1}$ were considered respectively as hazardous and conducive to fish growth.

Previous study reported a dramatic decline in food conversion efficiency and growth rate of sunfish (Lepomis spp.) when dissolved oxygen values remained between 3 and $4 \mathrm{mg} \cdot \mathrm{L}^{-1}$ (Miranda and Hodges 2000). A study on the effect of rearing density on growth and welfare of

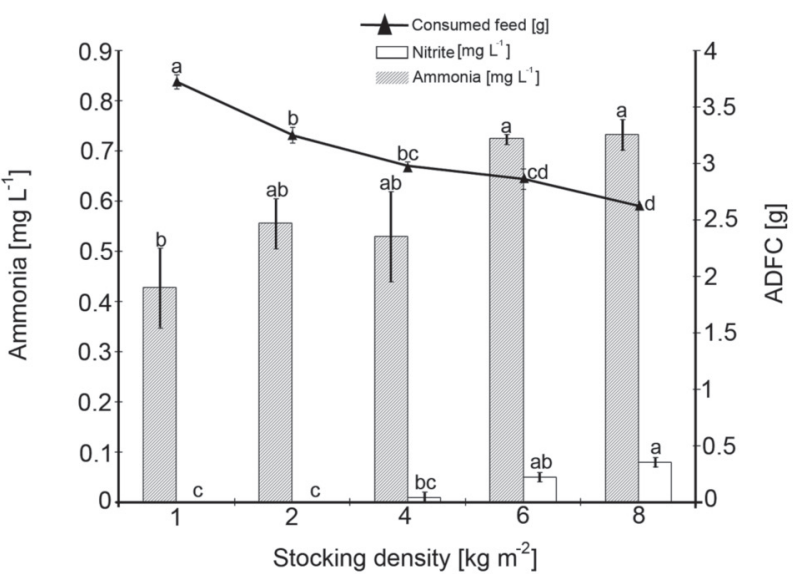

Fig. 4. The amounts of feed consumed, ammonia, and nitrite concentrations in outflow of rearing tank in juveniles of beluga, Huso huso, under different stocking densities; $\mathrm{ADFC}=$ the average of daily feed consumed during 56 days by a single fish; Different letters $(\mathrm{a}, \mathrm{b}, \mathrm{c}, \mathrm{d})$ indicate significant differences between lines under the same density $(P \leq 0.05)$

juvenile white seabream, Diplodus sargus, showed that the best overall performance (growth, food utilization, body protein content, liver fatty acids) is achieved under low density (Papoutsoglou et al. 2005). This result may be due to of the optimum conditions of water physical parameters with increase in density. In spite the fact that, the physicochemical parameters were not significantly different among treatments in Brycon cephalus, an inconsiderable change in water quality could reduce growth (Gomes et al. 2000).

The decreased feed utilization might be an indicator of the higher levels of stress encountered by the fish at higher densities. Maximum increase in fish biomass was found at the lowest stocking density, which decreased with increasing density because of better feed utilization and unstressed conditions at low stocking levels in our study. The same finding is also demonstrated by Al-Harbi and Siddiqui (2000). As the rate of growth tended to decrease as the stocking density increased (Vijayan and Leatherland 1988, Ross and Watten 1998, Gomes et al. 2000), there is a possibility that reduced growth rate could be a consequence of decreased food intake by crowding stress more than an adaptive strategy.

\section{CONCLUSION}

The results show that stocking density considerably influences the growth of beluga juveniles and water quality during 56 days of rearing. Results of this study reveal that the density of fish had a significant effect on water quality and a high density culture accompanied by reduction in feed consumption may result in high concentrations of ammonia, nitrite, and low concentrations of dissolved oxygen in the water of rearing tank. The ammonia concentrations were fairly high in all the experimental treatments. Although the statistical test did not show a significant difference between the most of treatments, 
there was definitely a trend of increasing ammonia concentration with increased density. Lower food consumption and higher competition at high densities could also be the result of stress due to high density of beluga (Rafatnezhad et al. 2008). Probably the amount of feed unconsumed accused of increase concentrations of nitrogen compounds. Therefore, changed water quality influences on beluga growth rate. Cold water species (i.e., trout; equivalent ammonia concentration $0.02 \mathrm{mg} \cdot \mathrm{L}^{-1}$ ) tend to be more sensitive to ammonia concentrations than warm water species (i.e., tilapia; equivalent ammonia concentration $0.6 \mathrm{mg} \cdot \mathrm{L}^{-1}$ ) (Timmons et al. 2002). The levels reported in this study exceeded the accepted level for cold water species in all treatments and exceeded the level for warm water species in 6 and $8 \mathrm{~kg} \cdot \mathrm{m}^{2}$ treatments.

There was an interacting effect of oxygen saturation and ammonia level on growth of beluga. Most likely the most important factors that are responsible for the differences in growth are primarily oxygen concentration and at the higher densities ( 6 and $8 \mathrm{~kg} \cdot \mathrm{m}^{-2}$ or 239 fish and 323 fish/tank), ammonia with oxygen concentrations. Therefore, some nitrogen compounds may reach to risky levels at high density of fish, but it never occurs in low density and it is possible to have an appropriate density during each phase of growth of beluga in order to have maximum production.

\section{ACKNOWLEDGEMENTS}

We acknowledge the staff at the Shahid Dr. Beheshti Sturgeon Fish Propagation and Rearing Complex for helping us during this project. The authors thank Dr. Sepahban Shamel, head of the central office of veterinary medicine in Guilan, Mohammad Ebrahimzadeh and Mohammad Heydari for providing technical facilities for water quality analysis. We also thank Ali Hamidoghli for his help in preparing the figure files.

\section{REFERENCES}

Al-Harbi A.H., Siddiqui A.Q. 2000. Effects of tilapia stocking densities on fish growth and water quality in tanks. Asian Fisheries Science 13 (13): 391-396.

Anonymous 1994. Water quality standards handbook. U.S. Environmental Protection Agency. Washington, DC, USA.

Anonymous 1998. Standard methods for the examination of water and wastewater. 19th edn. American Public Health Association, American Water Works Association, and Water Pollution Control Federation, New York, NY, USA.

Arillo A., Margiocco C., Melodia F., Mensi P., Schemone G. 1981. Ammonia toxicity mechanism in fish: studies on rainbow trout (Salmo gairdneri Rich.). Ecotoxicology and Environmental Safety 5 (3): 316-328. DOI: 10.1016/0300-9629(81)90056-6

Birstein V.J., Bemis W.E., Waldman J.R. 1997. The threatened status of acipenseriform species: a summary. Environmental Biology of Fishes 48 (1-4): 427-435. DOI: 10.1023/A: 1007382724251

Biswas J.K., Sarkar D., Chakraborty P., Bhakta J.N., Jana B.B. 2006. Density dependent ambient ammonium as the key factor for optimization of stocking density of common carp in small holding tanks. Aquaculture 261 (3): 952-959.

DOI: 10.1016/j.aquaculture.2006.08.021.

Boyd C.E. 1982. Water quality management for pond fish culture. Elsevier Scientific Publishing Company, Amsterdam, The Netherlands.

Brett J.R. 1979. Environmental factors and growth. Pp. 599-675. In: Hoar W.S., Randall, D.J., Brett J.R. (eds.) Fish physiology. Bioenergetics and growth. Vol. 8. Academic Press, New York.

Carlson A.R., Blocher J., Herman L.J. 1980. Growth and survival of channel catfish and yellow perch exposed to lowered constant and diurnally fluctuating dissolved oxygen concentrations. Progressive Fish-Culturist 42 (2): 73-78. DOI: 10.1577/1548-8659(1980)42[73:GASOCC]2.0.CO;2

Crocker C.E., Cech J.J.jr. 1996. The effects of hypercapnia on the growth of juvenile white sturgeon, Acipenser transmontanus. Aquaculture 147 (3-4): 293-299. DOI: $10.1016 / \mathrm{S} 0044-8486(96) 01411-1$

Ellis T., North B., Scott A.P., Bromage N.R., Porter M., Gadd D. 2002. The relationship between stocking density and welfare in farmed rainbow trout. Journal of Fish Biology 61 (3): 493-531. DOI: 10.1111/j.1095-8649.2002.tb00893.x

Fajfer S., Meyers L., Willman G., Carpenter T., Hansen M.J. 1999. Growth of juvenile lake sturgeon reared in tanks at three densities. North American Journal of Aquaculture 61 (4): $331-335$.

DOI: $10.1577 / 1548-8454(1999)$

Falahatkar B., Efatpanah I., Meknatkhah B., Arzboo Z., Ranaye Akhavan S. 2009a. Determination of the best feeding rate in great sturgeon juvenile during wintering feeding. 9th The University of Guilan Scientific Research Conference. 1-3 March 2009, Guilan, Iran.

Falahatkar B., Poursaeid S., Shakoorian M., Barton B. 2009b. Responses to handling and confinement stressors in juvenile great sturgeon Huso huso. Journal of Fish Biology 75 (4): 784-796.

DOI: $10.1111 / \mathrm{j} .1095-8649.2009 .02334 . \mathrm{x}$

Foss A., Vollen T., Øiestad V. 2003. Growth and oxygen consumption in normal and $\mathrm{O}_{2}$ supersaturated water, and interactive effects of $\mathrm{O}_{2}$ saturation and ammonia on growth in spotted wolffish (Anarhichas minor Olafsen). Aquaculture 224 (1-4): 105-116.

DOI: $10.1016 / \mathrm{S} 0044-8486(03) 00209-6$

Foss A., Kristensen T., Atland A., Hustveit H., Hovland H., Øfsti A., Albert K., Imsland A.K. 2006. Effects of water reuse and stocking density on water quality, blood physiology and growth rate of juvenile cod (Gadus morhua). Aquaculture 256 (1-4): 255-263.

DOI: $10.1016 /$ j.aquaculture.2006.02.032

Foss A., Imsland A.K., Roth B., Schram E., Stefansson S.O. 2009. Effects of chronic and periodic exposure to ammonia on growth and blood physiology in juvenile turbot (Scophthalmus maximus). Aquaculture 296 (1-2): 7-13. DOI: 10.1016/j.aquaculture.2009.07.013

Gomes L.C., Baldisserotto B., Senhorini J.A. 2000. Effect of stocking density on water quality, survival, and growth of larvae of the matrinxã, Brycon cephalus (Characidae), in 
ponds. Aquaculture 183 (1-2): 73-81.

DOI: $10.1016 / \mathrm{S} 0044-8486(99) 00288-4$

Jobling M. 1994. Fish bioenergetics. Chapman and Hall, London.

Jobling M. 1995. Simple indices for the assessment of the influences of social environment on growth performance, exemplified by studies on Arctic charr. Aquaculture International 3 (1): 60-65.

DOI: $10.1007 / \mathrm{BF} 00240922$

Koedijk R.M. 2005. Interactive effects of ammonia exposure and oxygen saturation on growth performance of juvenile cod (Gadus morhua). Master thesis, University of Wageningen, The Netherlands.

Miranda L.F., Hodges K.B. 2000. Role of aquatic vegetation coverage on hypoxia and sunfish abundance in bays of a eutrophic reservoir. Hydrobiologia 427 (1): 51-57. DOI: 10.1023/A:1003999929094

Mohseni M., Pourkazemi M., Bahmani M., Falahatkar B., Pourali H.R., Salehpour M. 2006. Effects of feeding rate and frequency on growth performance of yearling great sturgeon, Huso huso. Journal of Applied Ichthyology 26 (1): 278-282.

DOI: 10.1111/j.1439-0426.2007.00968.x

Papoutsoglou S., Karakatsouli N., Pizzonia G., Dalla C., Polissidis A., Papadopoulou-Daifoti Z. 2005. Effects of rearing density on growth, brain neurotransmitters and liver fatty acid composition of juvenile white sea bream Diplodus sargus L. Aquaculture Research 37 (1): 87-95.

DOI: $10.1111 / j .1365-2109.2005 .01401 . x$

Rafatnezhad S., Falahatkar B., Tolouei Gilani M.H. 2008. Effects of stocking density on haematological parameters, growth and fin erosion of great sturgeon (Huso huso) juveniles. Aquaculture Research 39 (14): 1506-1513.

DOI: $10.1111 / \mathrm{j} .1365-2109.2008 .02020 . \mathrm{x}$

Ross R.M., Watten B.J. 1998. Importance of rearing-unit design and stocking density to the behavior, growth and metabolism of lake trout (Salvelinus namaycush). Aquacultural Engineering 19 (1): 41-56.

DOI: $10.1016 / \mathrm{S} 0144-8609(98) 00041-7$

Salas-Leiton E., Anguis V., Manchado M., Cañavate J.P. 2008. Growth, feeding and oxygen consumption of Senegalese sole (Solea senegalensis) juveniles stocked at different densities. Aquaculture 285 (1-4): 84-89.

DOI: 10.1016/j.aquaculture.2008.08.001
Thurston R.V., Russo R.C., Vinogradov G.A. 1981. Ammonia toxicity to fishes. Effect of $\mathrm{pH}$ on the toxicity of the un-ionized ammonia species. Environmental Science and Technology 15 (7): 837-840.

DOI: $10.1021 / \mathrm{es} 00089 \mathrm{a} 012$

Timmons M.B., Ebeling J.M., Wheaton F.W., Summerfelt S.T., Vinci B.J. 2002. Recirculating aquaculture systems. NRAC Publication No. 01-002. Cayuga Aqua Ventures, Ithaca, NY.

Trenzado C., Morales A., Higuera M. 2006. Physiological effects of crowding in rainbow trout, Oncorhynchus mykiss, selected for low and high stress responsiveness. Aquaculture 258 (1-4): 583-593.

DOI: 10.1016/j.aquaculture.2006.03.045.

Vijayan M.M., Leatherland J.F. 1988. Effect of stocking density on the growth and stress-response in Brook charr, Salvelinus fontinalis. Aquaculture 75 (1-2): 159-170.

DOI: 10.1016/0044-8486(88)90029-4

Vlasenko A.D. 1994. Sturgeon status in the Caspian Sea. The International Conference on Sturgeon Biodiversity and Conservation. 28-30 July 1994, New York, NY, USA.

Wajsbrot N., Gasith A., Krom M.D, Popper D.M. 1991. Acute toxicity of ammonia to juvenile gilthead seabream Sparus aurata under reduced oxygen levels. Aquaculture 92: $277-288$.

DOI: $10.1016 / 0044-8486(91) 90029-7$

Wajsbrot N., Gasith A., Diamant A., Popper D.M. 1993. Chronic toxicity of ammonia to juvenile gilthead seabream Sparus aurata and related histopathological effects. Journal of Fish Biology 42 (3): 321-328.

DOI: $10.1111 / j .1095-8649.1993 . t b 00336 . x$

Whitworth W.R. 1968. Effects of diurnal fluctuations of dissolved oxygen on the growth of brook trout. Journal of Fisheries Research Board of Canada 25 (3): 579-584. DOI: 10.1139/f68-048

Wedemeyer G.A., Barton B.A., McLeay D.J. 1990. Stress and acclimation. Pp. 451-489. In: Schreck C.B., Moyle P.B. (eds.) Methods for fish biology. American Fisheries Society, Bethesda, MD, USA.

Received: 18 August 2010

Accepted: 14 November 2011

Published electronically: 31 December 2011 